кандидат педагогічних наук

(Барський гуманітарно-педагогічний коледж імені Михайла Грушевського) morozmaja@i.ua

ORCID: 0000-0001-5187-0434

\title{
ПРОФЕСІЙНА КОМПЕТЕНТНІСТЬ МАЙБУТНЬОГО ВЧИТЕЛЯ МУЗИКИ: СЕМАНТИЧНИЙ АНАЛІЗ ПОНЯТТЯ
}

У статті представлено семантичний аналіз понять "професійна компетентність", "професійна компетентність вчителя музики" у контексті історичного становлення ключових дефініцій. Доведено, щุо сучасний учитель музики - це фахівець, який повинен володіти, насамперед, мистецькою компетентністю, досконалими психолого-педагогічними знаннями, бути комунікативною, повноцінно сформованою особистістю, тобто бути професійно компетентним. Визначено умови формування професійної компетентності майбутніх вчителів музики, до яких віднесено організачійно-управлінські, навчально-методичні, технологічні та психолого-педагогічні.

Ключові слова: професійна компетентність, компоненти професійної компетентності, учитель музики, музично-педагогічна освіта.

Постановка проблеми у загальному вигляді та її зв'язок із важливими науковими і практичними завданнями. На сучасному етапі розвитку суспільства особистісно зорієнтована парадигма освіти ставить нові вимоги до здійснення навчально-виховного процесу. Значна увага звертається на максимальне розкриття потенціалу кожної людини, підготовки іiі до саморозвитку, самовизначення та самореалізації.

На професійну діяльність учителя покладена відповідальність за інтелектуальний та моральноестетичний розвиток підростаючого покоління. Проте виконання вчителем цих завдань залежить від того, наскільки адекватною є його професійна підготовка відповідно до вимог, поставлених суспільством перед системою державної освіти. Сьогодні досить важливого значення набувають питання художньоестетичної освіти та виховання учнів.

Реалізація завдань у сфері музичної освіти підростаючого покоління закладів загальної середньої освіти вимагає досить серйозної уваги до підготовки педагогічних працівників, формуванню у них відповідних професійних умінь. Адже без перебільшення можна сказати, що повноцінне й досконале музично-естетичне виховання вчителів - шлях до піднесення загальної музичної культури всього суспільства.

Аналіз основних досліджень і публікацій із зазначеної проблеми. Починаючи з XVII століття, 3 часів становлення педагогіки як науки (Я. А. Коменський - основоположник дидактики), професія вчителя отримала наукове обгрунтування в працях таких педагогів, учених, філософів, як Я. А. Коменський, І. Г. Песталоцці, Й. Ф. Гербарт, А. В. Дистервег, письменників та поетів Л. М. Толстого, Г. С. Сковороди, Т. Г. Шевченка. Вчені стверджували, що вчитель має бути чесною, діяльною, наполегливою людиною, живим взірцем доброчесності, яку потрібно прищеплювати учням; бути освіченим та працелюбним; безмежно любити свою справу; ставитися до учнів по-батьківськи, збуджувати інтерес учнів до знань.

Проблему професійної компетентності та професійного становлення особистості педагога досліджували вчені О. М. Алексюк, А. О. Афанас'єв, Л. М. Ахмедзянова, Г. О. Балл, В. М. Галузинський, С. У. Гончаренко, О. А. Дубасенюк, І. А. Зязюн, І. Ф. Ісаєв, Д. В. Іщенко, С. О. Клімова, В. Н. Кузьміна, А. К. Маркова, О. І. Пометун, В. О. Сластьонін, М. І. Сметанський, М. І. Томчук, тощо. У своїх працях вчені пропонують компонентну структуру особистісних якостей, які сприяють розвиткові та професійній діяльності педагога.

Окреслення невирішених питань, порушених у статті. Сучасний учитель музики - це фахівець, який повинен володіти, насамперед, мистецькою компетентністю, досконалими психологопедагогічними знаннями, бути комунікативною, повноцінно сформованою особистістю. Іншими словами - учитель музики повинен бути професійно компетентним. Сьогодні постає проблема у пошукові та вдосконаленні шляхів професійної підготовки майбутніх учителів музики на всіх освітніх рівнях, починаючи з фахової підготовки в педагогічних коледжах.

Формування професійно компетентного типу особистості педагога, визначення його фахового рівня як головної передумови вдосконалення професійно-художньої освіти, виділення особистісних характеристик майбутнього вчителя музики вимагають семантичного аналізу поняття "професійна компетентність".

Формулювання мети і завдань статті. У статті маємо на меті здійснити семантичний аналіз понять "професійна компетентність", "професійна компетентність учителя музики". 
Виклад основного матеріалу з обгрунтуванням отриманих наукових результатів. Питання про те, яким повинен бути вчитель, якими професійно-значущими якостями, знаннями та вміннями повинен він володіти, здавна цікавило не лише педагогів, але й філософів та письменників.

Історичний аналіз окресленої проблеми дозволяє нам спостерігати в судженнях та переконаннях педагога, філософа А. В. Дістервега досить чіткі вимоги до постійного професійного самовдосконалення вчителя. Вчений вважав, що вчителю треба знати історію, літературу, а також весь час слідкувати за новими працями $з$ педагогіки, психології, методики [1].

Ідея високого професіоналізму вчителя прослідковується і в судженнях українського педагога XIX століття К. Д. Ушинського, який був переконаний, що вчитель повинен володіти педагогічною майстерністю й педагогічним тактом. У педагогічних поглядах вчених XX століття (I. Я. Франко, Г. Ващенко, С. Русова, А. С. Макаренко, В. О. Сухомлинський) спостерігаємо зростання вимог до професійних якостей учителя. Зокрема, звертається увага на вміння вчителя наблизити шкільну науку до життя, "... щоб вся громада бачила її користь і поважала таке навчання й самого вчителя" [2: 92].

Як бачимо, проблеми, пов'язані з особистістю вчителя, його професійним рівнем, знаннями, вміннями не нові. Проте вимоги до професійних якостей педагога змінюються відповідно до часу. I якщо у XVII столітті учитель головним чином навчав та виховував учнів, забезпечував їхній розумовий розвиток (не забуваючи, звичайно, про духовне виховання), то з плином часу завданням учителя стало ще й навчити учнів використовувати отримані знання та вміння у реальному житті, приносячи цим самим користь усій громаді. Тобто, помічаємо активне впровадження соціальної функції освіти в цілому. Реалізація нових функцій освіти вимагає від учителя відповідних знань та професійних умінь. I саме тому в XXI столітті виводиться нова модель учителя - професійно компетентний учитель, який здатний реалізувати всі ті вимоги, що формувались у світовій освіті протягом віків. Завдання сучасного вчителя не тільки навчити і виховати, а й розкрити творчий потенціал своїх учнів, сформувати у них готовність до подальшої самореалізації та самовдосконалення у житті.

Сучасними вченими та педагогами-новаторами створено чимало авторських концепцій, досліджень, у яких пропонується власне бачення проблеми формування професійно компетентних учителів. Зокрема, маємо можливість проаналізувати погляди на поняття професійної компетентності учасників проектної групи під керівництвом Е. Р. Саїтбаєвої.

Учений А. О. Вербицький розглядає професійну компетентність через систему усвідомлених знань: "щоб бути теоретично і практично компетентним, студенту необхідно зробити подвійний перехід: від знака - до думки, а від думки - до вчинку, дії. Перехід від інформації до ііі використання опосередковується думкою, що і робить цю інформацію знанням" [3: 55]. Тобто, на думку вченого, головне в професійній компетентності - це знання, але знання свідомі, обгрунтовані, осмислені, у процесі набуття яких відбуваються складні мисленнєві процеси, що сприяє міцності та глибині їхнього формування.

Ідею ЗУНів, як першооснови професійної компетентності, підтримує також Л. М. Мітіна. Вона вважає, що поняття "педагогічна компетентність" включає знання, вміння, навички, а також способи та прийоми їх реалізації в діяльності, спілкуванні, розвитку (саморозвитку) особистості. Відповідно до визначення дослідниця виокремлює діяльнісний, комунікативний та соціальний компоненти професійної компетентності. Звичайно, перераховані компоненти окреслюють найважливіші аспекти професійної компетентності. Проте, на нашу думку, запропоновані компоненти потребують уточнення, розширення, а також детальнішого висвітлення такого важливого моменту, як способи та прийоми реалізації ЗУНів, тобто технологічного (методологічного) компоненту.

Саме про такий компонент згадує І. А. Зязюн. До компонентів професійної компетентності вчений відносить: знання предмета, методики його викладання, педагогіки й психології та рівень розвитку професійної самосвідомості, індивідуально-типові особливості й професійно-значущі якості [4: 34].

Професійну компетентність як систему знань, умінь та особистісних якостей, що відповідають змісту професійної діяльності, розглядають у своїх наукових дослідженнях такі українські вчені, як В. Краєвський, Н. Леонтьєва, І. Лернер, О. Олексюк, М. Станкін, Н. Трофімова.

Отже, аналіз поглядів учених А. О. Вербицького, Л. М. Мітіної, І. А. Зязюна, В. Краєвського, Н. Леонтьєвої, І. Лернера, О. Олексюка, М. Станкіна, Н. Трофімової на професійну компетентність та їі компоненти дозволяє зробити висновок, що ці вчені вбачають сутність професійної компетентності саме у системі ЗУНів, необхідних для подальшої професійної діяльності.

Схожими є погляди таких дослідників, як О. Крисан, О. Овчарук, О. Пометун, О. Локшина, О. Савченко, які вважають, що професійна компетентність $є$ своєрідним комплексом знань, умінь i ставлень, що набуваються в навчанні й дозволяють людині розуміти, тобто ідентифікувати та оцінювати в різних контекстах проблеми, що є характерними для різних сфер діяльності [5]. На нашу думку, у поглядах цих українських вчених точніше конкретизується, як саме буде реалізуватися набутий комплекс знань, умінь і ставлень, набутий у навчанні. А потрібні всі ці знання та вміння для можливості зрозуміти та оцінити ті моменти або проблеми, що виникають у процесі професійної діяльності. Тобто, йдеться, як 
ми вважаємо, про рефлексивно-регулятивний момент: здатність об'єктивно оцінити, проаналізувати та визначити шляхи розв'язання проблеми.

На відміну від учених-педагогів, згаданих вище, В. М. Введенський зауважує, що професійна компетентність педагога не зводиться до набору знань, умінь, а визначає необхідність та ефективність їх застосування в реальній освітній практиці. Як бачимо, визначення професійної компетентності, яке пропонує вчений, - лаконічне та має досить узагальнене формулювання. Але складові, які дослідник включає в це поняття, у повній мірі пояснюють та уточнюють визначення. Зокрема, В. М. Введенський передбачає такі компоненти професійної компетентності:

1. Комунікативна компетентність педагога - професійно значима, інтегративна якість, основними складовими компонентами якої є: емоційна стійкість (пов'язана 3 адаптовністю); екстраверсія (корелює зі статусом та ефективним лідерством); здатність конструювати прямий та зворотній зв'язок; мовні вміння; вміння слухати; вміння нагороджувати; делікатність; уміння робити комунікацію "гладкою".

2. Інформаційна компетентність включає об'єм інформації (знань) про себе, про учнів та їх батьків, про досвід роботи інших педагогів.

3. Регулятивна компетентність педагога передбачає наявність у нього вмінь управляти власною поведінкою. Вона включає: планування, мобілізацію та стійку активність, оцінку результатів діяльності, рефлексію. Головними факторами діяльності є моральні цінності.

4. Інтелектуально-педагогічну компетентність вчений розглядає як комплекс умінь з аналізу, синтезу, порівняння, абстрагування, узагальнення, конкретизації, як властивості інтелекту: аналогія, фантазія, гнучкість та критичність мислення.

5. Операційна компетентність визначається набором навичок, необхідних педагогу для здійснення професійної діяльності: прогностичні, проективні, предметно-методичні, організаційні, експертні навички педагогічної імпровізації.

Як бачимо, запропоновані компоненти за своєю суттю здебільшого перегукуються з компонентами інших вчених (Л. М. Мітіна, І. А. Зязюн та інші). Проте формулювання В. М. Введенського дещо відрізняються. Наприклад, операційний компонент В. М. Введенського подібний до діяльнісного компоненту Л. М. Мітіної, І. А. Зязюна, оскільки передбачає навички, необхідні педагогу для здійснення професійної діяльності.

Цікавою складовою професійної компетентності за $\quad$ В. М. Введенським $\epsilon$ інформаційна компетентність, яка передбачає наявність у педагога інформації (знань) про себе, про учнів та їх батьків, про педагогічний досвід роботи інших учителів. На нашу думку, ця складова у певній мірі перегукується з соціальним компонентом, який зустрічаємо в поглядах цілого ряду вчених (Л. М. Мітіна, І. А. Зязюн та ін.), оскільки передбачає діяльність у колективі, спілкування з різними соціальними групами людей.

Перераховані складові професійної компетентності, що пропонує В. М. Введенський, дозволяють зробити висновок, що вчений значну увагу приділяє тим чинникам, які дозволяють педагогові удосконалювати реально існуючі професійно-особистісні якості. Зокрема, це стосується регулятивного компоненту професійної компетентності, який передбачає вміння управляти власною поведінкою; рефлексію, як уміння оцінювати та аналізувати результати діяльності.

Рефлексивний компонент професійної компетентності зустрічаємо також і в поглядах В. І. Журавльова. Професійну компетентність учений розглядає як професійно-діяльнісну характеристику педагога, до якої відносить володіння педагогічними поняттями, концепціями, закономірностями, основами педагогічної інформатики, педагогічної діагностики, технологією педагогічної творчості, співробітництва з партнерами, управління колективними справами [6]. Рефлексію В. І. Журавльов відносить до умови, за якої виявляється професійна компетентність. Він поділяє ії на два типи: самооціночну та зовнішньо оціночну (відповідність кваліфікаційній характеристиці, володіння технікою методичної самооцінки через моделювання Я - концепції). Вчений виводить ще одну умову виявлення професійної компетентності: володіння знаннями про здоровий і розвиваючий спосіб життя, про способи виходу зі стресової ситуації; озброєння кожного педагога засобами соціального та психологічного захисту від впливу несприятливих факторів праці й життєдіяльності.

Отже, В. І. Журавльов виділяє дві головні умови - рефлексію та психолого-терапевтичні якості, які забезпечують виявлення професійної компетентності. Звичайно, названі умови - важливі. Реалізація окреслених характеристик вимагає від особистості наявності цілого ряду знань, достатнього рівня практичних умінь, чітко сформованих уявлень, переконань та професійних цілей, вмінь оцінювати власні досягнення, розуміння різноманітних педагогічних ситуацій та здатність розв'язувати виникаючі проблеми. I коли особистість оволодіє рефлексивними та психолого-терапевтичними техніками, вона буде спроможна виявляти й інші сторони професійної компетентності, зокрема, такі як технологія педагогічної творчості. А це вже новий, якісно вищий рівень професійності, без якого поняття компетентності буде неповним.

Творчий компонент присутній у переліку складових професійної компетентності вченого В. В. Радула. Серед основних компонентів він виділяє наступні: базові (наукові) знання та вміння; 
ціннісні орієнтації спеціаліста, мотиви його діяльності, стиль взаємовідносин із людьми, з якими він працює, педагогічна культура; здатність до розвитку свого творчого потенціалу. Аналіз засвідчує, що серед усіх складників вчений акцентує свою увагу саме на мотиваційно-ціннісних орієнтаціях спеціаліста. Ми погоджуємося з тим, що даний компонент повинен займати чільне місце серед складових професійної компетентності, адже це саме та рушійна сила, яка спонукає до активної діяльності, реалізації поставленої мети, творчості, самовдосконалення.

А. К. Маркова характеризує професійну компетентність - як таку працю вчителя, в якій на досить високому рівні здійснюється педагогічна діяльність, педагогічне спілкування, реалізується особистість учителя, в якій досягаються хороші результати навчання та виховання школярів. Дослідниця виокремлює наступні компоненти:

- ціннісно-смисловий компонент (професійні педагогічні позиції, установки вчителя, необхідні в його професіі);

- гностичний компонент (професійні (об’єктивно-необхідні) педагогічні знання);

- діяльнісний компонент (професійні (об’єктивно-необхідні) педагогічні вміння);

- особистісний компонент (особистісні якості, які забезпечують оволодіння учителем професійними знаннями та вміннями: педагогічні здібності, характер та його риси, психологічні процеси та стани особистості, педагогічна самосвідомість, індивідуальний стиль, креативність як творчий потенціал).

Як бачимо, дослідниця також виділяє мотивацію особистості серед усіх компонентів професійної компетентності. У наступних компонентах досить чітко та лаконічно розкриваються основні характеристики, якими повинен володіти компетентний спеціаліст. Звичайно, таких важливих компонентів, як комунікативний, соціальний, регулятивний А. К. Маркова не виділяє в окремі структурні одиниці (як це спостерігаємо у В. М. Введенського, Л. М. Мітіної, В. І. Журавльової , І. А. Зязюна та ін.), проте вони можуть передбачатися в діяльнісному та особистісному компонентах дослідниці.

Близькими до поглядів А. К. Маркової є погляди Т. Г. Браже Професійну компетентність він визначає як багатофакторне явище, що включає в себе систему знань та вмінь учителя, його ціннісні орієнтації, мотиви діяльності, інтегровані показники культури (мова, стиль, спілкування, відношення до себе та своєї діяльності, до суміжних сфер знань) [4: 30]. У визначенні вченого можна помітити, які саме компоненти вбачає Т.Г. Браже основними у професійній компетентності. Зокрема, це когнітивний (система знань та вмінь учителя), мотиваційно-ціннісний (ціннісні орієнтації, мотиви діяльності), комунікативний (спілкування), особистісний (мова, стиль, відношення до себе та своєї діяльності). Діяльнісного, як такого, компоненту у визначенні поняття професійної компетентності ми не помічаємо. Але все ж таки інтегровані показники культури (мова, стиль, спілкування, відношення до себе та своєї діяльності, до суміжних сфер знань) можна трактувати і як діяльність, оскільки перераховані властивості самі по собі - дієві.

Глибокі дослідження у сфері професійної компетентності провела дослідниця Н. Н. Лобанова. Професійну компетентність вона трактує як ключове поняття для характеристики педагогічної діяльності, яке визначає рівень педагогічної готовності до діяльності, є фактором збереження напрямку діяльності. Отже, дослідниця не мислить здійснення педагогічної діяльності без наявності професійної компетентності у педагога, тому трактує означене поняття як ключову характеристику професійної діяльності спеціаліста. Крім того, з визначення дослідниці стає зрозумілим, що професійно компетентний педагог - це обов'язково ціннісно сформована особистість, яка цілеспрямовано працює над професійним самовдосконаленням. Серед компонентів професійної компетентності Н. Н. Лобанова визначає професійно-змістовний, професійно-діяльнісний та професійно-особистісний (ціннісно-смисловий). Таке формулювання структурних компонентів дає досить чітке професійне спрямування, наголошуючи на тому, що всі дії та якості (тобто змістовне наповнення (ЗУНи), діяльність та особистісні характеристики) спрямовані на досягнення чітко поставленої мети та реалізацію суто професійних завдань. Що стосується змістовного компоненту, то пріоритетне місце у його структурі, за словами дослідниці, займають психолого-педагогічні та соціокультурні знання педагога.

Як бачимо, структурні компоненти, запропоновані Н. Н. Лобановою, у повній мірі розкривають сутність професійної компетентності та сприяють формуванню готовності до діяльності, як зазначала у своєму визначенні дослідниця.

Про професійну компетентність, як сукупність теоретичної та практичної готовності до здійснення педагогічної діяльності говорить і В. О. Сластьонін [7]. Структуру ж вчений розглядає через призму педагогічних умінь, які об'єднав у чотири групи:

1 - вміння "переводити" зміст об'єктивного педагогічного процесу в конкретні педагогічні завдання;

2 - вміння побудувати й привести в дію логічно завершену педагогічну систему;

3 - вміння виокремлювати й налагоджувати взаємозв'язки між компонентами та факторами педагогічного процесу, приводити їх у дію;

4 - вміння враховувати й оцінювати результати педагогічної діяльності [7: 102]. 
Цікавим та неординарним є підхід В. О. Сластьоніна до формулювання компонентів професійної компетентності: замість того, щоб називати складові компетентності загальними термінами, які мають досить широке наповнення не тільки ЗУНами, а й педагогічними діями, особистісними рисами, психологічними якостями та індивідуальним відношенням до педагогічних процесів, дослідник усе називає "вміннями". Хоча навіть при такому формулюванні ми можемо прослідкувати та віднайти певну схожість у змістовному наповненні компонентів Сластьоніна 3 іншими вченими. Наприклад, перший компонент Сластьоніна (вміння "переводити" зміст об'єктивного педагогічного процесу в конкретні педагогічні завдання) можна трактувати як чітке розуміння освітніх завдань, усвідомлення власного місця та призначення у педагогічній сфері, наявність мети та способів їі досягнення. Іншими словами це мотиваційно-ціннісний компонент, який знаходимо в дослідженнях В. В. Радул, А. К. Маркової, Т. Г. Браже, Н. Н. Лобанової та ін. Другий компонент вченого (вміння побудувати й привести в дію логічно завершену педагогічну систему) перегукується з діяльнісним компонентом, про який зазначають Н. Н. Лобанова, В. І. Журавльов, А. К. Маркова, В. М. Введенський, Л. М. Мітіна, І. А. Зязюн та ін. Ще один компонент В. О. Сластьоніна - вміння враховувати й оцінювати результати педагогічної діяльності - це рефлексивний компонент, присутній також у визначеннях В. І. Журавльова, В. М. Введенського На нашу думку, наголошення $\mathrm{B}$. О. Сластьоніним на тому, що структурні одиниці професійної компетентності - це вміння, свідчить про те, що вчений передбачав у такому формулюванні знання методики здійснення професійної діяльності. I саме наявність умінь, запропонованих вченим, i сприятиме формуванню готовності до професійної діяльності педагога.

Т. В. Добудько, опираючись на аналіз робіт Б. С. Гершунського, В. А. Ізвозчикова, А. К. Маркової, Л. М. Мітіної, Н.Н.Лобанової, пропонує визначення професійної компетентності, яке фактично співпадає $з$ визначенням В. О. Сластьоніна, зокрема: професійна компетентність педагога - це єдність його теоретичної та практичної готовності до здійснення педагогічної діяльності.

Автор обгрунтувала положення про те, що діяльнісна модель учителя співвідноситься з професійною компетентністю як "існуюче" (тобто те, що є) та "належне" (тобто те, що повинно бути). Як ми розуміємо, за теорією Т. В. Добудько, між реальною професійною діяльністю педагога та професійною компетентністю є певні розбіжності. Тому дослідниця пропонує наступні компоненти професійної компетентності, забезпечення яких дозволить педагогу бути професійно компетентним: науковотеоретичний, психологічний, операційно-технологічний. Безумовно, окреслені складові надзвичайно важливі у структурі професійної компетентності. Але оскільки психологічний та операційнотехнологічний компоненти передбачають діяльність та взаємодію з оточуючими, з соціумом, то, на нашу думку, доцільним було б виділення ще двох компонентів: комунікативного та соціального.

Заслуговують на увагу дослідження ще однієї вченої: Н. В. Кузьміної, яка трактує професійну компетентність як здатність педагога перетворювати спеціальність, носієм якої він є, у засіб формування особистості учня із врахуванням тих обмежень та вказівок, які накладаються на навчально-виховний процес вимогами педагогічної норми, в якій він здійснюється [8]. До складових компонентів дослідниця відносить:

1. Спеціальну та професійну компетентність у сфері певної дисципліни, що викладається.

2. Методичну компетентність у галузі способів формування знань та вмінь учнів.

3. Соціально-психологічну компетентність у сфері процесів спілкування.

4. Диференційно-психологічну компетентність у сфері мотивів, здібностей учнів.

5. Ауто психологічну компетентність у сфері переваг та недоліків власної діяльності та особистості.

Як бачимо, визначення та структурування професійної компетентності Н. В. Кузьміної відрізняється від визначень, аналізованих вище. По-перше, дослідниця говорить про професійну компетентність як про "здатність" (чого у попередніх проаналізованих судженнях ми не спостерігали). А це означає, що йдеться не лише про готовність до дії та знання про те, як саме діяти, а й про безпосередню професійну діяльність. По-друге, у визначенні йдеться про гнучкість, яку повинен проявляти компетентний педагог для того, щоб вирішувати завдання навчально-виховного процесу, що змінюються відповідно до вимог часу. По-третє, більшість компонентів професійної компетентності, запропоновані Н. В. Кузьміною, стосуються психологічного аспекту діяльності педагога (соціально-педагогічна, диференційованопсихологічна, ауто психологічна компетентності), спрямованого на глибоке вивчення учнівського колективу 3 метою створення сприятливих навчально-виховних умов, виявлення та усунення різноманітних труднощів та проблем, які стосуються психічного здоров'я учнів та сприятливого психологічного мікроклімату [8: 24].

Саме тому погляди Н. В. Кузьміної на сутність та структуру професійної компетентності є, на нашу думку, повнішими та грунтовнішими, ніж у попередніх дослідженнях.

Ідею спрямування професійної компетентності педагога на вивчення учнівського колективу, розвиток кожного учня залежно від індивідуальних задатків та здібностей підтримував український науковець В. Кремень. На його думку, компетентність вчителя виявляється у здатності супроводжувати процес 
самопізнання, саморозвитку учня, динамізувати його відповідно до конкретних сутнісних задатків кожної дитини [9: 2].

У такому підході до професійної компетентності педагога дійсно вбачається надзвичайний сенс. Адже вся професійна діяльність учителя спрямовується на всебічне, повноцінне формування особистості школяра. У цьому полягає найперше покликання педагога. I здатність (спроможність) реалізувати своє професійне покликання залежить від величезної кількості професійних та особистісних факторів педагога.

Глибокими та грунтовними є також дослідження вченого Є. І. Рогова, який компетентність пов’язує 3 поняттям професіоналізму. Як зазначає дослідник, професіоналізм - це сукупність психофізіологічних, психологічних та особистісних змін, які відбуваються в педагогові у процесі оволодіння та тривалого виконання діяльності, що забезпечує якісно новий, більш ефективний рівень вирішення складних професійних завдань в особливих умовах. Формування професіоналізму Є. І. Рогов пропонує здійснювати у трьох основних напрямках:

1) зміна всієї системи діяльності, їі функцій та ієрархічної будови. У процесі формування відповідних трудових навичок відбувається рух особистості по ступенях професійної майстерності, розвивається специфічна система способів виконання діяльності - формується особистий стиль діяльності;

2) зміна особистості суб'єкта, яка проявляється як зовнішньо (моторика, мова, емоційність, форми спілкування), так і у відповідних елементах професійної свідомості (професійна увага, перцепція, пам'ять, мислення, емоційно-вольова сфера), що в більш широкому плані може розглядатися як становлення професійного світогляду;

3) зміни відповідних компонентів установки суб'єкта по відношенню до об'єкта діяльності, що проявляється у когнітивній сфері (у рівні інформованості про об'єкт); в емоційній сфері (в інтересі до об'єкта, у здатності до взаємодії та задоволенні від цієї взаємодії, не дивлячись на труднощі); (у практичній сфері (в усвідомленні своїх реальних можливостей впливу на об'єкт). Відповідно до окреслених напрямків формування професіоналізму вчений виділяє такі основні компоненти: когнітивний, емоційно-ціннісний, практичний (діяльнісний).

Аналіз поглядів Є. І. Рогова на професійну компетентність (професіоналізм) педагога поряд iз знайомими нам компонентами дозволяе виділити ще й такі, що не проявлялися в попередніх дослідженнях. Зокрема, це врахування наступності у професійній освіті. Вчений зауважує, що професійна компетентність формується у процесі оволодіння та тривалого виконання діяльності, завдяки чому особистість піднімається на новий, якісно вищий щабель у своєму професійному розвитку, у неї 3'являється особистий стиль діяльності. А саме таку вимогу здатна забезпечити сьогодні ступенева професійна освіта.

Окрім того, у структурі професійної компетентності Є. І. Рогов відобразив емоційний компонент (гедоністичний), оскільки не применшує значимості позитивного відношення до обраної професії, отримання задоволення від виконуваної справи.

Інтеграцію всіх компонентів професійної компетентності, розглянутих нами вище, зустрічаємо у визначенні В. Шахова. На думку вченого, компетентність у сфері педагогічної діяльності містить теоретико-методологічні, психолого-педагогічні та дидактико-технологічні знання; діагностикопрогностичні, аналітичні, рефлексивні вміння; професійні педагогічні позиції, професійно важливі якості особистості; педагогічну ерудицію; педагогічне мислення (здатність до аналізу педагогічних ситуацій); педагогічну інтуїцію й імпровізацію; педагогічну спостережливість; педагогічний оптимізм; педагогічне прогнозування [10: 78]. Як бачимо, у власному розумінні професійної компетентності В. Шахов враховує ще й такий фактор, як педагогічна інтуїція та імпровізація. Враховуючи особливості вітчизняного освітнього простору, такі якості дійсно необхідні сучасному педагогові. Педагогічна практика засвідчує, що професійної гнучкості вчителя часом буває замало для того, щоб відреагувати на певні швидкі зміни. Надзвичайно важливо вміти передбачити, інтуїтивно відчути, прорахувати наперед ті чи інші освітні процеси та зуміти підготуватися до них. Крім того, як відомо, не завжди, навіть у повсякденній педагогічній діяльності, вчителеві вдається діяти по запланованому "сценарію", оскільки педагогічна діяльність - ні в якому разі не статична, вона рухлива, "жива", здійснюється у колективі, пов'язується зі спілкуванням $з$ різноманітними, особливими, не схожими один на одного людьми (учнями, колегами). Тому надзвичайно ціннісною є здатність педагога до професійної імпровізації, пов'язаної з умінням діяти "тут і тепер", без попередніх "заготовок", навіть якщо потрібно порушити заплановані моменти. Ось саме тут і з'являється у педагога можливість проявити всі свої професійні вміння, всю педагогічну майстерність. I тоді сміливо можна стверджувати про професійну педагогічну компетентність учителя.

Проаналізувавши різні погляди та підходи до визначення професійної компетентності, а також варіанти структурування даного поняття, ми бачимо, що у більшості випадків запропоновані характеристики перегукуються між собою, означення дослідників близькі за змістом. Проте, як засвідчив аналіз, усі визначення можна умовно розподілити на три групи: 
1 - визначення, в яких професійна компетентність трактується як система ЗУНів, призначена для виконання педагогічної діяльності;

2 - визначення, в яких професійна компетентність трактується як готовність до педагогічної діяльності;

3 - визначення, в яких професійна компетентність трактується як здатність виконувати педагогічну діяльність.

I хоч на перший погляд здається, що такі розбіжності у формулюванні не мають великого значення, проте ми вважаємо, що найбільш точним буде все ж таки розуміння професійної компетентності - як здатності здійснювати педагогічну діяльність, оскільки, на наш погляд, поняття "здатність" - повніше і включає в себе і систему ЗУНів, і готовність до діяльності.

Отже, яким би формулюванням не користувалися українські та зарубіжні вчені, які б складові компоненти не пропонували у своїх дослідженнях, беззаперечним $є$ той факт, що перш ніж навчати та виховувати когось (школярів, студентів тощо), перш ніж здійснювати практичну діяльність, педагог повинен сам чітко усвідомлювати своє професійне призначення, розуміти своє місце в освітньому просторі, мати чітку мету власної діяльності. Лише тоді педагог буде розуміти, чому і для чого він навчатиме своїх вихованців. Лише тоді, коли у педагога сформуються чіткі ціннісні орієнтири, він буде морально готовий до реалізації поставлених перед ним завдань.

Така мотиваційно-ціннісна основа спонукатиме спеціаліста до ефективнішого засвоєння теоретичних знань, формування системи практичних умінь та навичок, що сприятиме професійному зростанню та стане хорошим підгрунтям у подальшій професійній діяльності спеціаліста.

Звичайно, якщо ланцюжок мотиви - ЗУНи - діяльність наближає педагога до реалізації професійної мети, сприяє зростанню його педагогічної майстерності, то все це обов'язково призведе до емоційного задоволення власною навчальною та практичною (професійною) діяльністю, позитивного настрою та бажання професійно вдосконалюватися.

Накопичені у процесі професійної підготовки ЗУНи, звичайно, реалізуються у діяльності. Проте компетентність педагога вимагає від нього не просто діяльності (тобто репродуктивного застосування ЗУНів), творчого підходу до виконуваних завдань та обов'язків. Саме вміння переосмислювати, трансформувати наявні знання та вміння, експериментувати, створювати щось нове, своє власне, підніме педагога на вищий щабель професійного розвитку, що і передбачається у професійній компетентності. У процесі такої тривалої діяльності у спеціаліста формуватиметься досвід, який дозволить йому якісно зростати та вдосконалюватися.

Педагогічний досвід, накопичуючись у результаті професійної діяльності, допоможе спеціалістові гнучко реагувати та пристосовуватися до змін, які неодмінно присутні в будь-якому навчальновиховному процесі.

Оскільки професійна діяльність - багатокомпонентне, складне та варіативне явище, то педагог повинен володіти також рефлексивними вміннями. Застосовуються вони при здійсненні педагогом контрольно-оцінної діяльності, яка спрямовується, насамперед, на себе та свої дії. У процесі такого аналізу визначається правильність та доцільність поставленої мети, якість використовуваних форм та методів роботи, відповідність власної діяльності віковим особливостям учнів, причини успіхів та помилок, допущених при виконанні роботи. Об’єктивний самоаналіз допоможе, насамперед, спрогнозувати наступні дії, а також, визначивши власні помилки й недоліки у виконуваній роботі, усунути їх у процесі професійного самовдосконалення (саморозвитку, самоосвіти).

Висновки та перспективи подальшого дослідження проблеми. Таким чином, узагальнивши погляди вчених на структуру професійної компетентності, ми виділили наступні, які, на наш погляд, найповніше розкривають сутність досліджуваного поняття:

Ціннісно-мотиваційний (ціннісне ставлення до професії, ціннісне ставлення до подій та людей, готовність до виявлення власної ініціативи та подальшого професійного зросту);

когнітивно-гедоністичний (знання теоретичних та методологічних основ предметної сфери освіти, знання психолого-педагогічних основ сучасної освіти, знання вимог, які ставляться до сучасного вчителя, вміння отримувати задоволення не тільки від процесу навчання, але й від подальшої практичної діяльності);

технологічний (методологічний) (методичні, проективні, конструктивні, креативні, оціночні, інформаційні вміння);

особистісний (сукупність психічних властивостей, характерних рис; комунікативність, емоційний інтелект);

творчо-діяльнісний (творче вирішення освітніх завдань у процесі педагогічної діяльності; вміння змінювати, синтезувати отримані знання та вміння відповідно до педагогічних умов);

рефлексивно-прогностичний (вміння об’єктивно оцінювати власну педагогічну діяльність, визначати досягнення та недоліки, здатність виправляти помилки, прогнозувати свої наступні дії, обирати оптимальні шляхи вирішення освітніх завдань). 
Формування професійної компетентності майбутнього спеціаліста здійснюється шляхом отримання такої освіти, яка включатиме не тільки зміст предметної сфери, але й професійні навички та вміння, які формуються у процесі оволодіння предметом, а також у результаті активної позиції студента в соціальному та культурному житті ВУЗу. Все це буде спрямовуватися на підготовку майбутнього педагога, здатного до подальшого саморозвитку та самовдосконалення.

\section{СПИСОК ВИКОРИСТАНИХ ДЖЕРЕЛ ТА ЛІТЕРАТУРИ}

1. Дистервег А. О. О высшем принципе воспитания / А. О. Дистервег // Народное образование. - 1998. - № 4. C. $155-162$

2. Ващенко Г. Загальні методи навчання : [підручник для педагогів] / Г. Ващенко. - К. : Українська Видавнича Спілка, 1997. - 441 с.

3. Вербицкий А. А. Активное обучение в высшей школе : контекстный поход / А. А. Вербицкий. - М. : Высш. шк., 1991. - 207 с.

4. Зязюн І. А. Вдосконалення професійного розвитку особистості на основі технологізації освіти / I. А. Зязюн // Шкільні технології. - 2006. - № 1. - С. 41-45.

5. Сіданіч I. Професійна компетентність учителя та культура мислення учнів [Електронний ресурс] / I. Сіданіч// За матеріалами : Освіта.uа. - Дата публікації: 05.03.2008. - Режим доступу : http://osvita.ua/school/technol/1913/.

6. Журавлёв В. И. Стандарты в формировании и поддержании профессионализма педагогов / В. И. Журавлев // Проблемы обновления содержания общего образования. - Ростов-на-Дону : РПИ, 1992. - 100 с.

7. Сластенин В. А. Целостный педагогический процесс как объект профессиональной деятельности учителя / В. А. Сластенин, А. И. Мищенко. - М. : Прометей, 1997. - 200 с.

8. Кузьмина Н. В. Педагогическое мастерство учителя как фактор развития способностей учащихся / Н. В. Кузьмина // Вопросы психологии. - 1984. - № 1. - С. 23-28.

9. Кремень В. Г. Система освіти в Україні: Сучасні тенденції і перспективи // Професійна освіта: педагогіка і психологія / За ред. Т. Левовицького, І. Вілш, І. Зязюна, Н. Ничкало. - К. : Ченстохова, 2000. - С.11-31.

10. Шахов В. Базова педагогічна освіта майбутнього вчителя : загальнопедагогічний аспект / В. Шахов. Вінниця, 2007. - 383 с.

\section{REFERENCES (TRANSLATED \& TRANSLITERATED)}

1. Disterveg A. O. O vysshem printsipe vospitaniia [On the Supreme Principle of Education] / A. O. Disterveg // Narodnoe obrazovanie [Folk Education]. - 1998. - № 4. - S. 155-162.

2. Vashhenko G. Zagal'ni metody navchannia : [pidruchnyk dlia pedagogiv] [General Teaching Methods] / G. Vashhenko. - K. : Ukrains'ka Vydavnycha Spilka, 1997. - $441 \mathrm{~s}$.

3. Verbitsky A. A. Aktivnoe obuchenie v vysshei shkole : kontekstnyi podkhod [Active Learning in Higher Education: Contextual Hike] / A. A. Verbitsky. - M. : Vyssh. shk., 1991. - 207 s.

4. Ziaziun I. A. Vdoskonalennia profesiinogo rozvytku osobystosti na osnovi tekhnologizatsii osvity [Improvement of Professional Development of the Person on the Basis of Technology Education] / I. A. Zyazyun // Shkil'ni tekhnologii [School Technologies]. - 2006. - № 1. - S. 41-45.

5. Sidanich I. Profesiina kompetentnist' uchitelia ta kul'tura myslennia uchniv [Professional Competence of the Teacher and Culture of Student Thinking] [Elektronnyi resurs] / I. Sidanich // Za materialamy: Osvita.ua [According to Osvita.ua]. - Data publikatsii: 05.03.2008. - Rezhym dostupu : http://osvita.ua/school/technol/1913/.

6. Zhuravliov V. I. Standarty v formirovanii i podderzhanii professionalizma pedagogov [Standards in the Formation and Maintenance of Teachers' Professionalism] / V. I. Zhuravlev // Problemy obnovleniia soderzhaniia obshhego obrazovaniia [Problems of Updating the Content of General Education]. - Rostov-na-Donu : RPI, 1992. - $100 \mathrm{~s}$.

7. Slastenin V. A. Tselostnyi pedagogicheskii protsess kak obiekt professional'noi deiatel'nosti uchitelia [Holistic Pedagogical Process as an Object of Professional Activity of a Teacher] / V. A. Slastenin, A. I. Mishhenko. - M. : Prometei, 1997. $-200 \mathrm{~s}$.

8. Kuz'mina N. V. Pedagogicheskoie masterstvo uchitelia kak faktor razvitiia sposobnostei uchashkhihsia [Pedagogical Mastery of Teachers as a Factor in the Development of Students' Abilities] / N. V. Kuz'mina // Voprosy psikhologii [Psychology Questions]. - 1984. - № 1. - S. 23-28.

9. Kremen V. G. Systema osvity v Ukraini: Suchasni tendentsii i perspektyvy [The System of Education in Ukraine: Contemporary Trends and Perspectives] // Profesiina osvita : pedagogika i psykhologiia [Professional Education: Pedagogy and Psychology] / Za red. T. Levovytskogo, I. Vilsh, I. Ziaziuna, N. Nychkalo. - K. : Chenstokhova, 2000. - S. 11-31.

10. Shakhov V. Bazova pedagogichna osvita maibutniogo vchytelia : zagal'nopedagogichnyi aspekt [Basic Pedagogical Education of the Future Teacher: General Pedagogical Aspect] / V. Shakhov. - Vinnytsia, 2007. - 383 s.

\section{Мороз М. А. Профессиональная компетентность будущего учителя музыки: семантический анализ} понятия.

В статье представлены семантический анализ понятий "профессиональная компетентность",

"профессиональная компетентность учителя музыки" в контексте исторического становления ключевых дефиниций. Доказано, что современный учитель музыки - это специалист, который должен обладать, прежде всего, художественной компетентностью, совершенными психолого- 
педагогическими знаниями, быть коммуникативной, полноценно сформированной личностью, то есть

быть профессионально компетентным. Определены условия формирования профессиональной компетентности будущзих учителей музыки, к которым отнесены организационно-управленческие, учебно-методические, технологические и психолого-педагогические.

Ключевые слова: профессиональная компетентность, компоненты профессиональной компетентности, учитель музыки, музыкально-педагогическое образование.

\section{Moroz M. A. Professional Competence of the Prospective Teacher of Music: Semantic Analysis of the Concept.}

The article presents a semantic analysis of the concepts of "professional competence", "professional competence of the teacher of music" in the context of the historical formation of key definitions. It was found out that at the present stage of development of a society personally oriented paradigm of education sets new requirements for the implementation of the educational process. Considerable attention is paid to maximizing the disclosure of each person's potential, preparing for self-development, self-determination and self-realization.

It is substantiated that the modern music teacher is a specialist, who must possess, first of all, artistic competence, perfect psychological and pedagogical knowledge, be communicative, well-formed personality that is to be professionally competent. The conditions of professional competence formation of future teachers of music are classified as organizational, managerial, educational, methodological, technological and psychological and pedagogical.

It is proved that the formation of professional competence of the future specialist is carried out by obtaining such education, which will include not only the content of the subject area, but also the professional skills and skills that are formed in the process of mastering the subject, as well as a result of the active position of the student in the social and cultural life of the university. All this will be directed to the training of a prospective teacher, capable of further self-development and self-improvement.

Key words: professional competence, components of professional competence, teacher of music, musicalpedagogical education. 